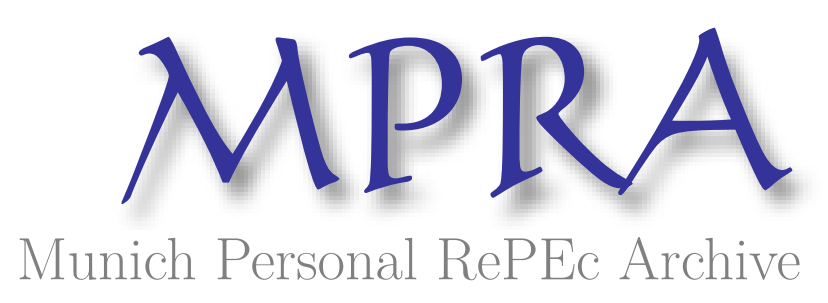

\title{
MANAGING FISHERIES \\ DEVELOPMENT IN MAHARASHTRA
}

Shah, Deepak

Gokhale Institute of Politics and Economics

9 July 2007

Online at https://mpra.ub.uni-muenchen.de/3924/

MPRA Paper No. 3924, posted 09 Jul 2007 UTC 


\section{MANAGING FISHERIES DEVELOPMENT IN MAHARASHTRA}

\section{Deepak Shah*}

\section{Introduction}

Fisheries is an important economic activity in developing countries like India. This country presents a vast scope for fish product from marine and inland resources. The vast aqua resources of our country harbour plenty of fish species distributed in its diversified ecosystems. Due to vast stretches of virgin lands, periodical monsoon rains, temperature and tropical climate, India has immense potential for aquaculture. In fact, recognizing the growth potential, the Government has identified the coastal marine fisheries as a thrust area and introduced a number of schemes and concessions with a view to augment the marine products exports. ${ }^{1}$ Like any other state, the fisheries sector of Maharashtra has undergone significant changes over the lat two decades. Recognizing the importance of fishery in the national economy, this paper attempts to evaluate the development of fisheries in the state of Maharashtra. It also identifies the problem areas and extends a few suggestions that could be considered as instrumental in formulating policies to give a real thrust to the fisheries sector of Maharashtra.

\section{Data and Methodology}

Data used for this study were collected from various secondary sources. Time series data for twenty years (1979-1999) on fisheries related parameters were collected from various issues of 'Handbook of Basic Statistics of Maharashtra State', Directorate of Economics and Statistics, Government of Maharashtra, Mumbai, and 'Statistical Abstract of India', Central Statistical Organization, Department of Statistics and Programme Implementation, Government of India, New Delhi, and also from the official records of fisheries department, Government of Maharashtra, Mumbai, and Planning Commission, Government of India, New Delhi.

In this study exponential trend equations have been fitted to the time series data obtained for various parameters from various sources in order to compute compound rates of growth that were also tested for their significance by the student ' $t$ ' statistics. ${ }^{2}$ Further, with a view to understand growth performance of various parameters better and in order to capture year to year fluctuations in the same, an index of instability ${ }^{3}$ as suggested by Coppock (1962) was also incorporated in the analysis, which appeared to have taken care of trend component in the time series data.

The study is divided into two sections. While the first section provides an insight into the changing structure in various fishery related indicators of Maharashtra, the second section is

\footnotetext{
* Faculty Member, Gokhale Institute of Politics and Economics (Deemed to be a University), Deccan Gymkhana, Pune - 411004 (Maharashtra)
} 
chiefly devoted to identification of problem areas, inferences and policy implications of the study, and various programme initiatives that need to be undertaken to truly transform the fisheries sector of Maharashtra.

\section{I - Indicators Governing Fisheries Development}

In India, the major fish producing states are: Andhra Pradesh, Assam, Karnataka, Kerala, Madhya Pradesh, Maharashtra, Orissa, Tamil Nadu, Uttar Pradesh and West Bengal. Among these states, Maharashtra accounts for a significant share insofar as marine fish production in the country is concerned. In comparison with Indian coastline of $8118 \mathrm{kms}$., the state of Maharashtra has $720 \mathrm{kms}$. of coastline with the continental shelf area of 111512 sq. kms. With a view to increase the quantum of fish production - both marine and inland, the state has introduced a number of schemes. The estimates relating to fish production in Maharashtra vis-à-vis India encompassing the period between 1979-80 and 1998-99 are provided in Table 1.

Table 1: Fish Production in Maharashtra vis-à-vis India: 1979/80 - 1998/99

\begin{tabular}{|c|c|c|c|c|c|c|c|c|}
\hline & & & & \multicolumn{5}{|c|}{ (in '000' Tonnes) } \\
\hline \multirow{3}{*}{ Fish Production } & \multirow{2}{*}{\multicolumn{3}{|c|}{$\begin{array}{c}\text { Triennium Average } \\
\text { Period }\end{array}$}} & \multicolumn{3}{|c|}{ Per cent Change } & \multicolumn{2}{|c|}{$1979-1999$} \\
\hline & & & & \multirow{2}{*}{$\begin{array}{c}2 \text { over } \\
1\end{array}$} & \multirow{2}{*}{$\begin{array}{c}3 \text { over } \\
2\end{array}$} & \multirow{2}{*}{$\begin{array}{c}3 \text { over } \\
1\end{array}$} & \multirow{2}{*}{$\begin{array}{c}\text { CGR } \\
(\%)\end{array}$} & \multirow{2}{*}{$\begin{array}{l}\text { CII } \\
(\%)\end{array}$} \\
\hline & 1 & 2 & 3 & & & & & \\
\hline \multicolumn{9}{|l|}{ Maharashtra } \\
\hline a) Marine & 340 & 372 & 436 & 9.41 & 17.20 & 28.24 & $1.37 *$ & 14.04 \\
\hline b) Inland & 25 & 61 & 112 & 144.00 & 83.61 & 348.00 & $7.40 *$ & 121.5 \\
\hline Total & 365 & 433 & 548 & 18.63 & 26.56 & 50.14 & $1.86^{* *}$ & 27.47 \\
\hline \multicolumn{9}{|l|}{ All-India } \\
\hline a) Marine & 1498 & 2347 & 2662 & 56.68 & 13.42 & 77.70 & $3.89 *$ & 6.71 \\
\hline b) Inland & 912 & 1549 & 2381 & 69.85 & 53.71 & 161.07 & $6.08 *$ & 4.78 \\
\hline Total & 2410 & 3896 & 5043 & 61.66 & 29.44 & 109.25 & $4.81 *$ & 4.77 \\
\hline \multicolumn{9}{|c|}{ Share of Maharashtra (\%) } \\
\hline a) Marine & 22.70 & 15.89 & 16.38 & -30.00 & 3.84 & -27.84 & $-2.43^{*}$ & 12.09 \\
\hline b) Inland & 2.74 & 3.94 & 4.70 & 43.80 & 19.29 & 71.53 & 1.25 & 121.1 \\
\hline Total & 15.15 & 11.11 & 10.87 & -26.67 & -2.16 & -28.25 & $-2.82 *$ & 27.93 \\
\hline
\end{tabular}

Source: Compiled from 'Handbook of Basic Statistics of Maharashtra' and 'Statistical Abstract of India' Notes: 1) Period 1: 1979/80 - 1981/82 ; Period 2: 1989/90 - 1991/92 ; Period 3: 1996/97 - 1998/99

2) CGR : Compound Growth Rate (annual) ; CII: Coppock Instability Index

$3) *$ and $* *$ indicate significance of growth rates at land 5 per cent level of probability

A critical evaluation of Table 1 reveals that though Maharashtra accounts for a significant share in total marine fish production of India, the share of Maharashtra in total fish production of India has declined over the past two decades mainly due to a sharp decline in her share in total marine fish production of India. While the share of Maharashtra in total marine fish production of India was estimated at 22.70 per cent during TE $1981-82$, it declined to 16.38 per cent by the TE 1998-99. Similarly, the share of Maharashtra in total fish production of India was also found to decline from 15.15 per cent during TE 1981-82 to 10.87 per cent by the TE 1998-99. The annual rate of decline in Maharashtra's share in total fish production of India is estimated at nearly 3 per cent between 1979 and 1999. The major decline in Maharashtra's share in total marine fish production of India is seen between TE 1981-82 and TE 1991-92 as in the subsequent period 
there has been marginal increase in her share in total marine fish production of India. There are several reasons for the slow growth in marine fish production of Maharashtra. These reasons and the steps to overcome the problem are delineated in the subsequent section.

Interestingly, the share of Maharashtra in total inland fish production of India has grown from 2.74 per cent during TE 1981-82 to 4.70 per cent by the TE 1998-99. Insofar as inland fisheries is concerned, Maharashtra has quite ambitious objectives. The major objectives of inland fisheries in Maharashtra are: (a) to maximize the inland fish production, (b) to increase per hectare fish production, (c) to improve socio-economic conditions of fishermen, and (d) to impart training to the fishermen and private entrepreneurs for self employment. These objectives have certainly given a real boost to inland fisheries in Maharashtra. At present, Maharashtra has about $3,16,998 \mathrm{Ha}$ area under fish culture and the length of river is about 16,000 kms. (GOM, 2003). As per the official records of fisheries department of Maharashtra, the inland fish production of Maharashtra has increased from 9,000 MT in 1959/60 to as high as 1,24,166 MT in 2001/02.

It is to be noted that Maharashtra produces as many as 32 varieties $^{4}$ of fish (Table 2). Among these varieties, shrimps, prawns, harpodon neherias, ribbon fish, otalithes, pomfrets, anchoviella, mackeral and cattle fish put together account for over 70 per cent share in total fish production of Maharashtra. All these varieties of fish have shown significant growth in their production during the period between 1989-90 and 1998-99. And, this is one of the reasons as to why total inland fish production of Maharashtra has grown significantly over time.

Table 2: Variety-wise Fish Production in Maharashtra: 1989/90 - 1998/99

\begin{tabular}{|c|c|c|c|c|c|c|c|c|c|}
\hline \multirow[b]{2}{*}{ Variety } & \multicolumn{2}{|c|}{ Triennium Ending } & \multicolumn{2}{|c|}{ 1989-1999 } & \multirow[b]{2}{*}{ Variety } & \multicolumn{2}{|c|}{ Triennium Ending } & \multicolumn{2}{|c|}{ 1989-1999 } \\
\hline & $1991 / 92$ & $1998 / 99$ & $\begin{array}{l}\text { CGR } \\
(\%)\end{array}$ & $\begin{array}{l}\mathrm{CII} \\
(\%)\end{array}$ & & $1991 / 92$ & $\begin{array}{c}1998 / 9 \\
9\end{array}$ & $\begin{array}{l}\text { CGR } \\
(\%)\end{array}$ & CII (\%) \\
\hline Elasmobranchs & 6.82 & 5.91 & -7.94 & 264.99 & Pomfrets & 8.50 & 15.82 & 7.67 & 49.59 \\
\hline Eels & 2.30 & 2.00 & -2.43 & 18.86 & Black Pomfrets & 1.16 & 2.02 & 6.59 & 58.05 \\
\hline Catfishes & 8.50 & 9.40 & 1.69 & 27.38 & Mackeral & 20.13 & 31.61 & 13.97 & 284.19 \\
\hline Chirocentrus & 2.85 & 4.77 & $6.21 *$ & 30.68 & Seer Fish & 5.19 & 10.50 & 8.03 & 74.53 \\
\hline Sardines & 5.26 & 7.71 & 3.23 & 66.19 & Tunnies & 2.53 & 4.94 & 10.85 & 98.61 \\
\hline Hilsa-Alisha & 1.69 & 0.58 & $-13.71 *$ & 37.63 & $\begin{array}{l}\text { Bregnaores } \\
\text { Noelillanid } \\
\end{array}$ & 0.74 & 0.97 & 0.75 & 67.72 \\
\hline Anchoviella & 18.92 & 19.09 & 0.07 & 16.51 & Soles & 5.41 & 5.36 & -0.31 & 44.08 \\
\hline Thrissoecles & 3.39 & 5.53 & $5.80 *$ & 24.64 & Leiggnathus & 1.96 & 1.28 & -5.10 & 112.22 \\
\hline Othercludedia & 4.17 & 4.05 & -0.19 & 100.12 & Carangids Small & 0.35 & 1.19 & $18.47 *$ & 125.60 \\
\hline $\begin{array}{l}\text { Harpodon } \\
\text { Neherias }\end{array}$ & 54.80 & 61.57 & 1.00 & 18.01 & Upenaides sp & 8.08 & 7.61 & -0.48 & 27.00 \\
\hline Perchos & 0.61 & 0.10 & $-21.18^{*}$ & 76.58 & Prawns & 34.66 & 39.06 & 1.39 & 10.48 \\
\hline Red Snapper & 0.23 & 0.80 & $16.12 *$ & 47.32 & Shrimps & 82.38 & 80.75 & -0.39 & 26.01 \\
\hline Polynomids & 0.30 & 0.42 & 4.97 & 63.13 & Lobsters & 0.61 & 0.28 & $-10.11 *$ & 26.08 \\
\hline Sciaemids & 1.29 & 3.43 & 16.60 & 124.00 & Lactarius & 1.24 & 1.88 & 5.15 & 51.40 \\
\hline Ribbon Fish & 19.44 & 23.35 & 1.79 & 59.62 & $\begin{array}{l}\text { Cattle Fish \& } \\
\text { Squids }\end{array}$ & 8.44 & 16.50 & $7.62 *$ & 34.95 \\
\hline Otalithes sp & 16.70 & 19.45 & $2.05 *$ & 9.85 & Miscellaneous & 31.28 & 29.71 & -0.35 & 18.65 \\
\hline Caranx & 3.35 & 3.88 & 2.67 & 41.37 & Total & 363.26 & 424.23 & $2.02 * *$ & 12.29 \\
\hline
\end{tabular}

Note: 1) CGR : Compound Growth Rates ; CII: Coppock Instability Index

2 ) * and ** indicate significance of growth rates at 1 and 5 per cent level of probability 
A further analysis drawn from Table 3 shows that in Maharashtra Brihan Mumbai and Thane regions alone account for about 60 per cent of the total inland fish catch of Maharashtra. The other inland fish catch regions of Maharashtra are Raigad, Ratnagiri, and Sindhudurg. Although Brihan Mumbai and Thane account for bulk of the total inland fish catch of Maharashtra, the shares of these regions have declined marginally over the course of time.

Table 3: Share of Different Regions in total Variety-wise Fish Production of Maharashtra

\begin{tabular}{|c|c|c|c|c|c|}
\hline \multirow{2}{*}{ Regions } & \multicolumn{2}{|c|}{ Triennium Ending } & \multirow{2}{*}{ Per cent Change } & \multicolumn{2}{|c|}{ 1989-1999 } \\
\hline & $1991 / 92$ & $1998 / 99$ & & CGR $(\%)$ & CII $(\%)$ \\
\hline \multicolumn{6}{|c|}{ Production (in '000' Tonnes) } \\
\hline Thane & 88.80 & 110.29 & 24.20 & 1.81 & 20.01 \\
\hline Brihan Mumbai & 135.71 & 150.79 & 11.11 & 1.82 & 17.38 \\
\hline Raigad & 47.74 & 48.80 & 2.22 & 0.32 & 29.63 \\
\hline Ratnagiri & 59.65 & 74.69 & 25.21 & 1.35 & 49.50 \\
\hline Sindhudug & 31.20 & 39.66 & 27.12 & 5.45 & 47.53 \\
\hline Total & 363.10 & 424.23 & 16.84 & $2.02^{* * *}$ & 12.29 \\
\hline \multicolumn{6}{|l|}{ Share (\%) } \\
\hline Thane & 24.46 & 25.97 & - & -0.20 & 15.12 \\
\hline Brihan Mumbai & 37.38 & 35.54 & - & -0.20 & 12.78 \\
\hline Raigad & 13.15 & 11.50 & - & -1.67 & 19.43 \\
\hline Ratnagiri & 16.43 & 17.61 & - & -0.66 & 51.80 \\
\hline Sindhudug & 8.59 & 9.35 & - & 3.37 & 41.42 \\
\hline
\end{tabular}

Although Maharashtra has shown declining share in total fish production of India, as against this decline, the state has shown considerable increases in the quantum strength of marine-fishing villages/hamlets, boats engaged in fishing, fish brought for curing, salt issued, cured fish removed, besides showing increases in number of fish cooperative societies and their membership, etc. (Table 4). Among these fisheries related indicators, the major growth is seen in number of fish cooperative societies, quantity of fish brought for curing, salt issued and cured fish removed. These are certainly positive features of development of fisheries in Maharashtra.

The state of Maharashtra has also shown a significant and rather more sharp growth in her induced fish breeding practices, particularly during the period between TE 1991-92 and TE 1998-99. Similarly, the marketing of fish in the state has also grown significantly over time. However, the point that merits attention is the decline in total inland water spread area of the state, which has gone down from 310 thousand hectares to 300 thousand hectares between TE 1981/82 and TE 1998/99. The major reason for this could be attributed to increasing urbanization in Maharashtra. Another disquieting feature of fisheries sector of Maharashtra is the decline in the number of fish curing yards, which have come down by 45 per cent during the period under consideration. On the other hand, the number of fishery schools have stagnated at nine in the state over the last two decades. 
Table 4: Fisheries Related Indicators of Maharashtra

\begin{tabular}{|c|c|c|c|c|c|c|c|c|}
\hline \multirow{3}{*}{ Particulars } & \multirow{2}{*}{\multicolumn{3}{|c|}{$\begin{array}{c}\text { Triennium Average } \\
\text { Period } \\
\end{array}$}} & \multicolumn{3}{|c|}{ Per cent Change } & \multicolumn{2}{|c|}{ 1979-1999 } \\
\hline & & & & \multirow{2}{*}{$\frac{2 \text { over }}{1}$} & \multirow{2}{*}{$\frac{3 \text { over }}{2}$} & \multirow{2}{*}{$\frac{3 \text { over }}{1}$} & \multirow{2}{*}{$\frac{\text { CGR }}{(\%)}$} & \multirow{2}{*}{$\begin{array}{l}\mathrm{CII} \\
(\%)\end{array}$} \\
\hline & 1 & 2 & 3 & & & & & \\
\hline 1.Total Coastline of State (in Kms.) & 720 & 720 & 720 & - & - & - & - & - \\
\hline 2.MarineFishing Villages/Hamlets (No.) & 375 & 386 & 391 & 2.93 & 1.30 & 4.27 & Neg. & - \\
\hline 3.Boats Engaged in Fishing (No.) & 12503 & 15712 & 18345 & 25.67 & 16.76 & 46.73 & $2.24^{*}$ & 2.72 \\
\hline 4.Boats Above One Tonne (No.) & 6834 & 9061 & 13005 & 32.59 & 43.53 & 90.30 & $4.21 *$ & 5.91 \\
\hline \multicolumn{9}{|l|}{ 5.Mechanised Boats (No.) } \\
\hline a) Departmentally & 3058 & 3939 & 4544 & 28.81 & 15.36 & 48.59 & $2.07 *$ & 22.60 \\
\hline $\begin{array}{l}\text { b) Existing (including mechanised } \\
\text { by other agencies) }\end{array}$ & 4072 & 7047 & 8734 & 73.06 & 23.94 & 114.49 & $4.41^{*}$ & 5.27 \\
\hline $\begin{array}{l}\text { 6.Quantity of Fish Brought for Curing } \\
\text { (in Tonnes) }\end{array}$ & 8384 & 3083 & 15093 & -63.22 & 389.56 & 80.02 & 8.38 & 173.1 \\
\hline 7. Quantity of Salt Issued (in Tonnes) & 1732 & 697 & 2885 & -59.76 & 313.92 & 66.57 & 8.12 & 181.5 \\
\hline $\begin{array}{l}\text { 8. Quantity of Cured Fish Removed } \\
\text { (in Tonnes) }\end{array}$ & 6420 & 2140 & 10820 & -66.67 & 405.61 & 68.54 & 8.22 & 167.5 \\
\hline 9. No. of Fish Cooperative Societies & 535 & 1547 & 2202 & 189.16 & 42.34 & 311.59 & $8.92 *$ & 50.18 \\
\hline 10. Membership of Coops. (in '000') & 177 & 190 & 221 & 7.34 & 16.32 & 24.86 & $2.29 *$ & 27.96 \\
\hline $\begin{array}{l}\text { 11. Total Inland Water Spread Area } \\
\text { (in ‘000’ Ha) }\end{array}$ & 310 & 301 & 300 & -2.90 & -0.33 & -3.23 & & \\
\hline \multicolumn{9}{|l|}{ 12. Carp Fish Stocked (in '000’ No.) } \\
\hline a) Improved & - & 179974 & - & - & - & - & & \\
\hline b) Induced Breeding & 28400 & 65649 & 251421 & 131.16 & 382.98 & 785.28 & $12.39 *$ & 131.2 \\
\hline 13. Fish Curing Yards (No.) & 20 & 7 & 11 & -65.00 & 57.14 & -45.00 & $-1.95^{*}$ & 23.10 \\
\hline 14. Fishing Schools (No.) & 9 & 9 & 9 & - & - & - & - & - \\
\hline 15.Coop. Boat Building Yards (No.) & 1 & 1 & 1 & - & - & - & - & - \\
\hline \multicolumn{9}{|l|}{ 16.Disposition of Fish Catch (in Tonnes) } \\
\hline a) Marketing Fresh & - & 278380 & 384533 & & 38.13 & - & $5.74 *$ & 15.61 \\
\hline b) Freezing & - & 40705 & - & & - & - & & \\
\hline c) Sun Dried & - & 123886 & 116439 & & -6.01 & - & -1.50 & 49.41 \\
\hline d) Salted & - & 5921 & 7835 & & 32.33 & - & 3.82 & 38.15 \\
\hline e) Canning & - & - & - & & & - & & \\
\hline f) Reduction & - & 24452 & 27496 & & 12.45 & - & $2.88 * *$ & 22.94 \\
\hline g) Miscellaneous Purpose & - & & - & & - & - & & \\
\hline Total & - & 473344 & 536303 & & 13.30 & - & $3.87 *$ & 13.40 \\
\hline
\end{tabular}

The declining trends in inland water spread area, numerical strength of fish curing yards and stagnant number of fishery schools are certainly disturbing features of the fisheries sector of Maharastra. The declining share of Maharashtra in India's total fish production over the past two decades is another negative feature that requires attention by various policy makers.

Interestingly, some of the fisheries related indicators such as induced fish breeding, quantity of fish brought for curing, quantity of salt issued and cured fish removed have shown very high growth rates associated with high degree of fluctuations (Table 4). In fact, this high degree of fluctuation in these indicators is found during the period between TE 1991-92 and TE 1998-99. However, high degree of fluctuation associated with high growth rate as noticed in the case of inland fish production of Maharashtra is mainly during the first half as compared to the second half of the overall period (Table 1). On the other hand, the number of fish cooperative societies in Maharashtra has grown significantly with very high rate of growth associated with moderate rate of fluctuation during the given period of time. The marketing of fish in Maharashtra is noticed to be stable as the disposition of fish catch of Maharashtra, in general, has grown significantly with very low rate of fluctuation. 


\section{II - Inferences, Suggestions and Policy Implications}

Although Maharashtra accounts for 14-20 per cent of the total marine fish production of India - which is almost stable over the past five years, the present fishing fleet of the state is not capable to exploit the deep sea resources. The state has formulated a scheme to introduce a medium size craft to exploit the resources in the depth of 70 fathoms with prolonged fishing cruise of 15 to 20 days in comparison to the present existing level of 4 to 10 days. This scheme so far has not given rich dividend. In fact, the major problem faced by the marine fisheries of Maharashtra is relating to depletion of resources due to illegal presence of foreign vessels and vessels belonging to other states, which appeared to have created pressure on the coast line. As a result, the marine fish production of Maharashtra has grown at very low pace during the last two decades (Table 1). In order to tackle this problem, there is need for the Government of India to introduce zonalisation of coast line in the National Fishing Policy. This will not only help in stopping illegal presence other state's and foreign vessels but also in checking the depletion of resources. Some loop holes in the existing fishing laws should also be checked to prevent any illegal presence of vessels which deplete the marine resources.

Notably, Maharashtra Fisheries Regulation Act (MHFRA) was introduced in the state in 1981. As per the provisions made in the Act, the mesh size of cord end of trawl net has been specified for different areas. And, these sizes are strictly followed. However, in order to maintain the existing marine fish stock there is need for the Government of India to implement uniform ban on illegal entry of other vessels in different coastal areas.

It is to be further noted that the declining trends in inland water spread area, numerical strength of fish curing yards and stagnant number of fishery schools are certainly disturbing features of the fisheries sector of Maharashtra. However, in order to develop fisheries sector, the department of fisheries in the state is conducting various training programme relating to carp fish seed production, fresh water prawn culture, integrated fish farming and management of aquarium, etc.

In order to develop fisheries sector in Maharashtra, there is need to educate fishermen with respect to dissemination of information relating to modern/mechanized fishing techniques and efficient marketing of fish catch. Equally important is the need for more innovative technologies in this sector, diffusion of developed technology by extension workers and adoption by the clients. Education of fishermen about modern fishing techniques is reported to have a significant impact on adoption of recommended fish culture practices by the farmers (Sivasankar, et.al., 1995). It is also pointed out that extension and mass media participation have strong positive relationship with adoption of fish culture practices (Prabhakara and Murthy, 1994). Nonetheless, inadequate infrastructure and flow of information technology have been cited as the major barriers for better market integration in the existing marine fish markets of India (Behura and Pradhan, 1998). 
As for the overall development of fisheries sector of India, it is to be noted that since the target of fish production of 5.6 lakhs tons for 2003-04 was lower than the target of 6.3 lakhs tons for 2002-03, measures need to be taken to increase production of both marine and inland capture fisheries from reservoirs, etc. and culture fisheries to increase the overall fish production. There is also scope for exploitation of off-shore and deep sea fishery resources through introduction of newly designed fuel saving multi-day mechanized fishing vessels and deep sea fishing vessels (Planning Commission, GOI, 2004). The need for the multi-day mechanized fishing vessels as well as the deep sea vessels is also felt in the state of Maharashtra.

\section{Notes}

1. It is to be noted that 100 per cent export oriented units are extended several concessions that mainly encompass: (a) duty free input and capital goods, (b) raw materials free from excise duty and central levis, and (c) green card entitlement for allotment in matters of raw materials, power clearance and foreign exchange (James et al. 1993).

2. The equation fitted to analyse the trend is semi-log exponential form

$$
\begin{array}{lll}
\mathrm{y} & = & \mathrm{e}^{\mathrm{A}+\mathrm{Bt}} \\
\log \mathrm{y} & =\mathrm{A}+\mathrm{B} * \mathrm{t}
\end{array}
$$

The compound growth rates $(r)=\left(e^{\mathrm{B}}-1\right) \times 100$ were tested for their significance by the student 't' statistics.

3. According to Coppock, the annual instability index equals the anti-log of the square root of the logarithmic variance. The series is given in algebraic form as follows :

$$
\begin{gathered}
\mathrm{V} \log =\frac{1}{\mathrm{~N}-1} \\
\text { or } \\
\left.\mathrm{V} \log =\frac{\left[\log \mathrm{X}_{\mathrm{t}+1}-\log \mathrm{X}_{\mathrm{t}}-\frac{1}{\mathrm{~N}-1} \sum\left(\log \mathrm{X}_{\mathrm{t}+1}-\log \mathrm{X}_{\mathrm{t}}\right)\right]^{2}}{\mathrm{X}_{\mathrm{t}+1}-\mathrm{m}}\right]^{2} \\
\mathrm{N-1}
\end{gathered}
$$

Where, $\mathrm{N}=$ Number of years $; \mathrm{X}=$ Value of the parameter $\mathrm{m}=$ Mean value of the logarithmic first difference

4. These varieties of fish are: Elamorbranchs, Eals, Catfishes, Chirocentrus, Sardines, Hilsha- Alisha, Anchoviella, Thrissoecles, Othercludedia, Harpodon Neherias, Perchos, Red Snapper, Polynomids, Sciaemids, Ribbon Fish, Otalithes sp, Caranx, Pomfrets, Black Pomfrets, Mackeral, Seer Fish, Tunnies, Bregnaores Noelillanid, Soles, Leiggnathus, Carangids Small, Upenaides sp, Prawns, Shrimps, Lobsters, Lactarius, Cattle Fish \& Squibs, etc. 


\section{References:}

Behura, Debdutt and Durga Charan Pradhan (1998), 'Cointegration and Market Integration: An Application to the Marine Fish Markets in Orissa', Indian Journal of Agricultural Economics, Vol. 53, No.3, pp. 344-350.

Coppock, J.D. (1962), 'International Economic Instability', McGraw-Hill Publishing Company, New York.

Government of Maharashtra (2003), Official Records, Department of Fisheries, Mumbai.

Government of India (2004), Official Records, Planning Commission, New Delhi.

James, P.S.B.R., D.B.S. Sehara and Narayana Kumar (1993), 'Prospects for Marine Fisheries Development in the New Economic Environment', Agricultural Situation in India, Vol. 48, No.5, pp. 345-351.

Prabhakara, S and H.G. Shankara Murthy (1994), 'Economics of Mechanized Fishing Boats in Coastal Karnataka', Agricultural Situation in India, Vol.49, No. 1, pp. 15-18.

Sivakumar, N., A. Bheemappa and K.B.Umesh (1995), 'A Study on the Adoption of Scientific Fish Culture by the Farmers of Tungabhadra Command Area in Raichur District, Karnataka, Agricultural Situation in India, Vol.49, No. 12, pp. 907-910. 